\title{
The use of English subtitled video on Youtube to improve students' vocabulary achievement
}

\author{
Kiromil Baroroh $^{1}$, Huzairin ${ }^{2}$, Novita Nurdiana ${ }^{3}$ \\ English Education Study Program, University of Lampung \\ kiromilbaroroh2@gmail.com ${ }^{1}$
}

\begin{abstract}
This quantitative research was conducted to see if the use of English subtitled video on YouTube is effective to increase students' vocabulary achievement, and to investigate the students' perception on the use of English subtitled video on YouTube in vocabulary learning. The researcher used one group pretest and posttest design. The sample of this research was IX C students at SMP Negeri 1 Ambarawa. The instruments used in this study were vocabulary test and questionnaire. The data were analyzed by using Repeated Measures T-Test in Statistical Package for Social Science (SPSS) software in which the significance was determined by $\mathrm{p}<0.05$. The result of the research showed that the mean score of pretest was 4.6 while the posttest was 6.1 with 1.5 different points. The result of t-value (6.049) was higher than t-table (2.045), and the value of significance was $0.000>0.05$. It indicated that the hypothesis was accepted; therefore, there is a significant difference between students vocabulary achievement after teaching by using English subtitled video on YouTube. Moreover, the researcher used close-ended questionnaire to investigate the students' perception after the implementation of English subtitled video on YouTube in vocabulary learning. The result of the questionnaire showed that the use of the medium was enjoyable, effective, and beneficial for students to learn vocabulary. This was proven by the result of the percentage of each item of the questionnaire which showed more than 70\%. Thus, based on the result, it is concluded that English subtitled video on YouTube can be applied to increase students' vocabulary achievement.
\end{abstract}

Keywords:Effective,Perception, Subtitled Video, Vocabulary

\section{INTRODUCTION}

Vocabulary, as stated by Diamond and Gutlohn(2006), is about words and their meanings that language learners might use. This is in line with Richard and Renandya(2002) who stated that students need vocabulary as a core component of language proficiency in order to listen, speak, read, and write well. Furthermore, Nation (2001) indicates that words are dealt with as they happen to occur. English vocabulary consists of several hundred thousand words. Therefore, teachers and students are challenged to achieve as many of them.

However, Supangesti et al. (2014) reported that the ninth-grade students of SMPN 1 Singkawang acknowledged that it was really difficult to understand the English text because they did not know a lot of words used in the passage. Another research conducted by Yuksel and Tanriverdi (2009) found that EFL students in Turkey have difficulty in developing their vocabulary knowledge. Similarly, Lestari (2018) stated that the students become lazy to learn English, they are afraid to speak and even get bored when they have to learn it.

Concerning this, Sherman (2003) suggested that videos can be used as resources to learn vocabulary with enjoyment and give students a lot of advantages. In line with this, Rokni and Ataee (2014) have found that using subtitles with movies, in general, affects language learning positively. Moreover, Aloqaili (2014) found out that subtitled videos can be used as an effective 
learning tool in vocabulary learning. As Talavan (2014) suggested that the great value of video lies in its combination of sounds, images, and sometimes text (in the form of subtitles). With respect to subtitled video, Thanajaro (2000) remarks the use of authentic videos in ESL or EFL classrooms has a positive effect on learners' motivation to learn the language.

In relation to Sadiku's statements (2018) above, numerous studies have examined the effect of using English subtitled video and have shown positive effects in EFL classrooms. For example, a previous study conducted by Angkananon and Wald (2018) at SuratthaniRajabhat University in Thailand showed that the scores of the experimental group were higher than the control group after the implementation of online video and subtitles which also helped the students learn English words better than just learning face-to-face with similar techniques. In Indonesia, Azizi and Aziz (2019) in SMK Sultan TajulAriffin showed that there is a significant improvement in the experimental group compared to the control group after watching the video. Ridarma (2017) also found that the second-grade students of MAN 3 Rukoh Banda Aceh had more interest in the media which helped a lot in understanding the pronunciation and vocabulary. Lestari (2018) also found that the use of English subtitle in movie gave the effect to increase ninth-grade students' vocabulary mastery in SMPN 1 Gunungsari. While watching subtitled movies, students are not only watching and listening to the audiovisual material but also interacting with it as they translate the source text into the target language (Gorjian, 2014).

In regards to the use of online videos in online classroom activity, the study conducted by AlJarf (2016) showed that the use of YouTube in online courses helps motivate and enhance EFL students' learning and acquisition of English vocabulary. YouTube offered statistically significant effects on students' vocabulary acquisition which indicates that the participants positively viewed the use of YouTube in their lessons (Heriyanto, 2015). Additionally, the study conducted by Hakim (2019) showed that the use of YouTube videos is effective in teaching vocabulary for young learners and the students have a positive perception of using YouTube to learn vocabulary. Further, Widat (2017) presented in his research that the majority of students also had positive perception toward the implementation of authentic video with subtitle. In sum, perception is very important in understanding the students' behavior, because every student perceives the understanding differently. This will also help the teachers to find out whether their teaching technique is effective or not.

Based on the problems above, the research questions to be formulated are: 1) whether the use of English subtitled video on YouTube gives a significant difference on students' vocabulary achievement and 2) the students' perception toward the implementation of the medium.

\section{METHODS}

This research was aimed at finding if there was a significant difference between students' vocabulary achievement after being taught by using English subtitled video on YouTube, and investigating students' perception toward the use of the medium in vocabulary learning. One group pretest and posttest design (T1 X T2) was used in this research. The formula of the design is proposed by Setiyadi(2018). 


\section{Participants}

The population of this research is the ninth grade students of SMP Negeri 1 Ambarawa. There are seven classes in the ninth grade of SMP Negeri1 Ambarawa. Each class consists of 30-32 students. The researcher used one class in this research as the representative. The sample of this research is 30 students of IX C class as suggested by the teacher. In determining the sample, the researcher used purposive sampling.

\section{Instruments}

The first instrument used in this research is vocabulary test. The aim is to see the students' vocabulary achievement before and after the implementation of the treatments. Additionally, there are two kinds of tests, those are pretest and posttest. Pretest was administered before giving the treatments in order to find out the students' initial achievement in vocabulary. Meanwhile, posttest was administered after the implementation of the medium. Moreover, questionnaire was also used in this research to investigate the students' perception toward the use of the medium in vocabulary learning.

\section{Data Analysis}

In order to answer each of the research question, the data has been analyzed through the following steps: 1) calculating the mean of pretest and posttest; 2) analyzing the data by using Paired Sample T-Test in SPSS to see the significant difference between students' vocabulary achievement after being taught by using the medium; 3) analyzing the result of the questionnaire by calculating the percentage of the gained score; 4) classifying the students' level of perception by using the following criteria proposed by Ratminingsih et al.(2017):

Table 1. Criteria of Questionnaire

\begin{tabular}{|cl|}
\hline Percentage & \multicolumn{1}{c|}{ Criteria } \\
\hline $\mathrm{Pc} \geq 85 \%$ & Very positive \\
\hline $70 \leq \mathrm{Pc} \leq 84$ & Positive \\
\hline $55 \leq \mathrm{Pc} \leq 69$ & Moderate \\
\hline $40 \leq \mathrm{Pc} \leq 54$ & Negative \\
\hline $\mathrm{Pc} \leq 39$ & Very negative \\
\hline
\end{tabular}

\section{RESULTS AND DISCUSSIONS}

\section{Result}

After getting the result of pretest and posttest, the mean score of both tests were compared in order to analyze the improvement of students' score. The mean score of pretest was 3.9while in posttest was 5.3. In result, the increase amounted to 1.4 points. The following table shows the results of the hypothesis of students' mean score of the tests.

Table 2. Paired Samples T-Test

\begin{tabular}{|c|c|c|c|c|c|c|c|c|}
\hline & \multicolumn{5}{|c|}{ Paired Differences } & \multirow[b]{3}{*}{$\mathrm{t}$} & \multirow[b]{3}{*}{ df } & \multirow{3}{*}{$\begin{array}{l}\text { Sig. (2- } \\
\text { tailed) }\end{array}$} \\
\hline & \multirow[b]{2}{*}{ Mean } & \multirow{2}{*}{$\begin{array}{c}\text { Std. } \\
\text { Deviation }\end{array}$} & \multirow{2}{*}{$\begin{array}{l}\text { Std. } \\
\text { Error } \\
\text { Mean }\end{array}$} & \multicolumn{2}{|c|}{$\begin{array}{l}\text { 95\% Confidence } \\
\text { Interval of the } \\
\text { Difference }\end{array}$} & & & \\
\hline & & & & Lower & Upper & & & \\
\hline $\begin{array}{ll}\text { Pair } & 1\end{array}$ & & & & & & & & \\
\hline POSTTEST & 1.43333 & .97143 & .17736 & 1.07060 & 1.79607 & 8.082 & 29 & .000 \\
\hline
\end{tabular}


As shown in the table above, it can be seen that the significant value is .000. It means that $\mathrm{H} 1$ is accepted since 0.000 is lower than 0.05 . It is evident that the t-value (8.082) is higher than ttable (2.045); therefore, there is a significant difference between students' vocabulary achievement after being taught by using English subtitled video on YouTube since 8.082> 2.045 ( $\mathrm{t}$-value is higher than t-table). In addition, by comparing the mean score of pre-test and posttest, it was found that the students' score improved 1.4 points from 3.9 to 5.3. In sum, there is an improvement on students' vocabulary achievement after being taught by using English subtitled video on YouTube.

Moreover, after analyzing the result of the questionnaire, the final result was calculated as can be noticed in the table below.

Table 3. The Gained Score of the Questionnaire

\begin{tabular}{|clccc|}
\hline No. & \multicolumn{1}{c}{ Indicator of the Questionnaire } & $\begin{array}{c}\text { Max } \\
\text { Score }\end{array}$ & $\begin{array}{c}\text { Gained } \\
\text { Score }\end{array}$ & Percentage \\
\hline 1. & $\begin{array}{l}\text { The Students' Perception on the } \\
\text { Implementation of English Subtitled Video }\end{array}$ & 360 & 312 & $86.66 \%$ \\
\hline $2 . \quad \begin{array}{l}\text { The Students' Perception on the } \\
\text { Effectiveness of English Subtitled Video in } \\
\text { Vocabulary Learning }\end{array}$ & 480 & 431 & $89.79 \%$ \\
\hline 3. & $\begin{array}{l}\text { The Students' Perception on the Benefits of } \\
\text { the Use of English Subtitled Video on } \\
\text { YouTube in Vocabulary Learning }\end{array}$ & 960 & 801 & $83.43 \%$ \\
\hline & Total & 1800 & 1544 & $85.77 \%$ \\
\hline
\end{tabular}

The table above clearly indicates that the percentage of each indicator of the questionnaire is more than $70 \%$. Additionally, after calculating the gained score and maximum score, it was obtained $85.77 \%$ in total, indicating that the students had a positive perception on the use of English subtitled video in vocabulary learning. Finally, it can be stated that the implementation of English subtitled video on YouTube is effective and advantageous for students to learn vocabulary.

\section{Discussion}

As stated earlier that the researcher successfully conducted this research through WhatsApp group chat in six meetings. The pretest and posttest were given to the students in the beginning and at the end of the meeting to investigate whether there is an improvement on students' vocabulary achievement. The mean score of students' vocabulary in pretest was considered lower compared to the result in posttest. Therefore, the students' vocabulary achievement showed an improvement because the mean of students' posttest is higher than in pretest. Furthermore, to find out the significant difference score between pretest and posttest, the researcher analyzed the data by using Paired Sample T-Test.

Further, after the data was collected and analyzed, the comparison between the students' mean score in posttest (5.3) showed 1.4 points higher compared to in pretest (3.9). Similarly, the calculation of the significant difference using Paired Sample T-Test using SPSS version 20 showed that the $\mathrm{t}$-value gained 8.082 which were higher than $\mathrm{t}$-table which showed 2.045 . The 
same formula was used to find out the significant level and 0.00 was obtained as the significant level of the pretest and posttest. Thus, all of the evidences proved that there is a significant difference between students' vocabulary achievement after being taught by using English subtitled video on YouTube.

Regarding to the previous study, this research supports a study conducted by Rahayu (2014) investigating the improvement of the seventh-grade students' vocabulary mastery after the implementation of English subtitled video as the media. The result showed that there was an improvement of students' vocabulary mastery which was indicated by the mean of pretest that was 76.41 , while the mean of posttest was 84.94.

With respect to another study, the finding also supports a quantitative research conducted by Ridarma (2017). He investigated the significant difference score of eleventh-grade students' vocabulary achievement after being taught by using English subtitled video. The result showed that the mean score of posttest was higher than in pretest. Thus, English subtitled video was proven to improve students' vocabulary achievement.

Based on the present studies, it proved that English subtitled video was beneficial for students in learning vocabulary. It can be seen from the significant difference between the mean of pretest and posttest which has been analyzed.

In relation to the second research questionthat is about the students' perception toward the use of English subtitled video on YouTube in vocabulary learning, it is critical to consider the students' feeling and perspective during and after the implementation of the medium, thus questionnaire was required to support this research.

The questionnaire was close-ended questionnaire in which the scale was given based on the Thurstone Scale with responses ranging from 'Strongly Agree', 'Agree', 'Disagree', and 'Strongly Disagree', each of which had one response category's score, that is 4,3,2, and 1 . There were 15 items of questionnaire which classified into three indicators. In calculating the score, the researcher divided the gained score by maximum score and presented the result in form of percentage.

The result presented in table 3 proved that there was positive perception among majority of students toward the use of English subtitled video in vocabulary learning. It can be seen from the percentage of each indicator which showed more than $70 \%$ that means positive based on the criteria of perception. The students believed that the video was fun and enjoyable. Moreover, they thought that the video was interesting and better to apply in vocabulary learning compared to the other ones. Furthermore, the medium was advantageous for them to improve their vocabulary knowledge, particularly in terms of meaning and word use. In general, most students agreed that the video was beneficial to improve their vocabulary achievement. In contrast, there were 1-4 students disagreed with some statements. The highest percentage for 'disagree' was in item number 5 with the statement about the English subtitled video was better used than other media to apply in vocabulary learning. It occurred since each student had his own preference in learning, mainly in vocabulary learning. Still, most students chose 'agree' with the statement.

The finding of this second research question also supports the previous research conducted by Widat (2017) who investigated the students' response on authentic subtitled video in vocabulary 
learning. In his research, it was obtained that $74.84 \%$ of university students had positive responses toward the strategy usage. In brief, based on the discussion of the finding, it can be summarized that the use of English subtitled video gave a positive result on students' vocabulary achievement.

\section{CONCLUSIONS AND SUGGESTIONS}

After the research had been conducted at the ninth grade of SMPN 1 Ambarawa and the data had been analyzed, it can be concluded that teaching vocabulary by using English subtitled video on YouTube is effective to improve students' vocabulary achievement. This is supported by the teaching and learning process which was successfully done without any significant obstacles. In addition, not only has English subtitled video helped the students in achieving new vocabulary, but also using it in sentences since some of the vocabulary used in the test had been learned by the students from the video. Hence, the implementation of English subtitled video on YouTube is significantly improved the students' vocabulary knowledge. In addition, the use of the medium has a positive impact on students' vocabulary achievement. The students considered the use of English subtitled video an enjoyable and exciting medium to learn vocabulary. Moreover, they also thought that it helped them learning new vocabulary easily. In brief, the students agree that English subtitled video on YouTube is effective and advantageous for them to learn vocabulary.

Moreover, this study has implications. Teachers are suggested to apply English subtitled video on YouTube in teaching vocabulary since it was proven to be effective in improving students' vocabulary achievement. However, since there were some students who did not actively join the teaching-learning process, it is better for the teacher to be more creative in conducting the teaching and learning process. Furthermore, the result of the questionnaire showed positive perception among students', it is suggested for the English teachers to use English subtitled video on YouTube as an additional medium in teaching vocabulary for another topic such as descriptive text, recount text, etc. In relation to this, further research is expected to investigate different English skills achievement such as students' speaking achievement, students' writing achievement, etc.

\section{REFERENCES}

Al-Jarf, R. (2016). Teaching vocabulary to EFL college students online. Computer Assisted Language Learning Electronic Journal, 8 (9).

Aloqaili, G. S. (2014). Learning vocabulary from subtitled videos: an investigation into the effectiveness of using subtitled videos for intentional vocabulary learning in saudi arabia with an exploration of learners' perspective. British Council ELT Master's Dissertation Awards: Commendation. Southampton University Press.

Angkananon, K., \& Wald, M. (2018). Experimental study of subtitled online video supporting thai students learning english.Teaching English with Technology, 18(4), 48-70.

Azizi, S., \& Aziz, A. A. (2019). The effect of intralingual caption on students' vocabulary learning.International Journal of Advanced Research in Education and Society, 1(3), 1222.

Diamond, L., \& Gutlohn, L. (2006). Vocabulary handbook. Brookes Publishing Company.

Gorjian, B. (2014). The effect of movie subtitling on incidental vocabulary learning among EFL learners. International Journal of Asian Social Science, 4(9), 1013-1026.

Hakim, L. N. (2019). The implementation of youtube in teaching vocabulary for young learners.Journal of Advanced English Studies, 2(1), 13-18. 
Heriyanto, D. (2015). The effectiveness of using youtube for vocabulary mastery. English Teaching Journal (ETERNAL), 6(1), 1-12.

Lestari, R. C. (2018). The use of english subtitle in movie to improve students 'vocabulary: An exprimental study in grade IX of SMPN 1 Gunungsari in academic year 2015/2016.Academic Journal of Educational Sciences, 1(1), 19-23.

Nation, P. (2001). Learning vocabulary in another language.English for Specific Purposes, 23(1), 87-90.

Rahayu, N. P. (2014). The effectiveness of using english subtitled video towards students' vocabulary achievement at MTSAl-Huda Bandung.Institutional Repository of IAIN Tulungagung.

Ratminingsih, N. M., Artini, L. P., \& Padmadewi, N. N. (2017). Incorporating self and peer assessment in reflective teaching practices.International Journal of Instruction, 10(4), $165-184$.

Richard, J., \& Renandya, W. (2002). Methodology in language teaching, an anthology of current practice. Cambridge University Press.

Ridarma, M. A. (2017). Mastering vocabulary and pronunciation through viewing english subtitled videos.Englisia Journal (EJ (1).

Rokni, S., \& Ataee, A. (2014). The effect of movie subtitles on efl learners' oral performance.International Journal of English Language, Literature and Humanities, $1(\mathrm{~V})$, 201-215.

Sadiku, A. (2018). The role of subtitled movies on students' vocabulary development. International Journal of Sciences: Basic and Applied Research (IJSBAR), 42, 212-221.

Setiyadi, B. (2018). Metode penelitian untuk pengajaran bahasa asing: Pendekatan kuantitatif dan kualitatif (2nd ed.). Graha Ilmu.

Sherman, J. (2003). Using authentic video in the language classroom. Cambridge University Press.

Supangesti, P., Sutapa, G., \& Salam, U. (2014). Using video subtitles to improve students' reading comprehension in narrative text.Jurnal Pendidikan Dan Pembelajaran Khatulistiwa, 7(5), 1-12.

Talavan, N. (2014). Learning vocabulary through authentic video and subtitles. TESOL-SPAIN Newsletter, June.

Thanajaro, M. (2000). Using authentic materials to develop listening comprehension in the english as a second language classroom.

Widat, B. (2017). The effectiveness of authentic subtitled videos in enhancing students vocabulary skill: the case study of first year lmd students at mostaganem. University of Abdulhamid Ibn Badis Mostaganem.

Yuksel, D., \& Tanriverdi, B. (2009). Effects of watching captioned movie clip on vocabulary development of efl learners.The Turkish Online Journal of Educational Technology TOJET, 8(2), 48-54. 